\title{
Physicochemical qualities of stored fresh cut EVIARC sweet jackfruit (Artocarpus heterophyllus Lam.) pulp as influenced by deseeding, packaging method and storage condition
}

\author{
Anne Gellie P. Pablo', Lorina A. Galvez ${ }^{2 \star}$, Roberta D. Lauzon ${ }^{2}$ and Yan Diczbalis ${ }^{3}$
}

\begin{abstract}
Processing method plays a significant role in the physicochemical property of food products. This study evaluated the effects of deseeding, packaging method, and storage condition on the physicochemical properties of fresh-cut jackfruit during the 8-day storage period. A $2 \times 2 \times 2$ factorial experiment was used in the study with a total of 8 treatments. All of the treatments were subjected to physicochemical analysis following standard protocols. Data were subjected to single factorial Analysis of Variance (ANOVA) and multi-factorial ANOVA for the interaction of dependent variables. Jackfruit pulps which were deseeded have shown significant decrease in the physicochemical attributes of the product which is an indicator for product quality. Deseeded products had much faster deterioration compared to treatments with intact seeds. Treatments stored in chilling $\left(4-6^{\circ} \mathrm{C}\right)$ condition exhibited lesser variation in TA, TSS, $\mathrm{pH}$, browning and firmness during the storage period compared to those stored at ambient temperature. Chilled treatments packed in vacuum had slower deterioration compared to treatments which were conventionally packed.
\end{abstract}

Keywords: EVIARC sweet jackfruit, minimally processed, jackfruit, quality evaluation, low-temperature storage, vacuum packed

\section{INTRODUCTION}

Jackfruit is a huge fruit of about $50 \mathrm{~kg}$ (Coronel1983) that is becoming more popular in the market due to its unique flavor and health benefits. EVIARC Sweet jackfruit variety contains phenolics, tannins, reducing sugar, sulfur and antioxidants (Galvez \& Dizon 2017), which have functional properties for human health. One way

\footnotetext{
${ }^{1}$ Instructor, College of Agriculture Forestry \& Environmental Sciences, Western Philippines University

${ }^{2}$ Department of Food Science \& Technology, Visayas State University, Visca, Baybay City, Leyte

${ }^{3}$ Queensland Department of Agriculture Fisheries and Forestry, Australia

*Corresponding Author. Address: Department of Food Science and Technology, Visayas State University, Visca, Baybay City, Leyte; Email: Iorina.galvez@vsu.edu.ph DOI: 10.32945/atr41111.2019
} 
Physicochemical qualities of stored fresh cut

of producing a high value product from this fruit is through minimal processing, which can also reduce its weight.

Freshcut products are highly perishable due to the disruption of tissue and cell integrity with a concomitant increase in the enzymatic, respiratory and microbiological activity, leading to reduction of the shelf life of these products (Olusola 2002 as cited by Fagundes et al 2013). These products generally have higher respiration rates than the corresponding intact products. Higher respiration rates indicate a more active metabolism and usually a faster deterioration rate. In addition, higher respiration rates can result in more rapid loss of acids, sugars and other components that determine flavor quality and nutritive value (Cantwell \& Suslow 2002).

In general, freshcut fruits are rinsed just after cutting with cold $\left(0\right.$ to $1^{\circ} \mathrm{C}, 32$ to $34^{\circ} \mathrm{F}$ ) chlorinated water at $\mathrm{pH} 7.0$. This may help extend product shelf life by reducing microbial load, removing cellular juices at cut surfaces that may promote cut surface discoloration, and actually inhibiting the enzymatic reactions involved in fruit browning (Brecht et al 1993, Hurst 1995). However, post-cut washing or dipping may have negative consequences such as increased water activity and "washing away" of desirable flavor attributes.

Cantwell and Suslow (2013) also mentioned that the physical damage or wounding caused by preparation increases respiration and ethylene production within minutes, with associated increase in rates of other biochemical reactions responsible for changes in color (including browning), flavor, texture, and nutritional quality (sugar, acid and vitamin content). The degree of processing and the quality of the equipment significantly affect wounding response.

Strict temperature control is required to minimize increased respiration rates of freshcut products. Low temperature storage is also essential to retard microbial spoilage on cut surfaces. Cantwell and Suslow (2013) cited that the increased oxygen demand due to the higher respiration rates of freshcut products dictates that packaging films maintain sufficient permeability to prevent fermentation and off-odors. Hence, this study was conducted to investigate the relationship of deseeding, packaging method and storage condition to the physicochemical properties of minimally processed jackfruit.

\section{MATERIALS AND METHODS}

\section{Procurement of Materials}

EVIARC Sweet jackfruit was procured from the farm of Job Abuyabor in Mahaplag, Leyte, Philippines. The chemicals, namely; sodium hypochlorite, calcium chloride and ascorbic acid, as well as other materials were procured from commercial sources in Cebu City, Philippines. Packaging materials were bought in Baybay City, Leyte.

\section{Preparation and Processing of Fresh-Cut Jackfruit}

The jackfruit was washed with soap and water, scrubbed until visually clean from adhering organic matter (leaves, soil, stems). The whole fruit was sanitized with chlorine solution of $100 \mathrm{ppm}$ concentration equivalent to $0.01 \%$ solution and 
was sliced longitudinally. The pith was removed and fruit pulps were segregated from the seeds and other jackfruit byproducts. The jackfruit pulps were trimmed and only those undamaged were used. A combination of food grade sodium hypochlorite $(\mathrm{NaOCl}=0.04374 \% \mathrm{~W} / \mathrm{v})$, calcium chloride $\left(\mathrm{CaCl}_{2}=0.74 \% \mathrm{w} / \mathrm{v}\right)$ and ascorbic acid solution $(0.65 \% \mathrm{w} / \mathrm{v})$ were prepared as pretreatment solution (Patindol 2016) with little modification. A total of $20 \mathrm{~L}$ of pretreatment solution was prepared. The pulps, about $10 \mathrm{~kg}$, were soaked into the pretreatment solution (20L) for $2 \mathrm{~min}$. Product was put into sanitized hanging baskets to remove excess water.

After draining off the liquid, treatments were packed in respective containers. Each pack contained $200 \mathrm{~g}$ of jackfruit pulp. For vacuum packaging, polyethylene bags with $0.003 \mathrm{~mm}$ thickness were used. The product was vacuumed for 25 seconds and sealed at medium heat for 3 seconds. For conventional packaging, plastic tray and cling wrap was used. Treatments $1,3,5$, and 7 were stored at chilled condition (crisper) $\left(4-6^{\circ} \mathrm{C}\right)$, and the remaining treatments $(2,4,6 \& 8)$ were stored at ambient condition $\left(30^{\circ} \mathrm{C}\right)$ (Table 1). Chilled refrigerator temperature was monitored using a thermometer for cold storage. A controlled air-conditioned room set at $30^{\circ} \mathrm{C}$ was used for the storage of products at ambient condition. The vacuum-packed samples were placed on the sanitized trays on the sanitized table in the airconditioned room.

\section{Experimental Design}

A 2x2x2 factorial design was employed to compare the different responses of physicochemical properties to the variables. Table 1 shows the different treatments with their corresponding variables.

Table 1. Experimental combinations of jackfruit pulp preparation, packaging method and storage condition in preparation of the treatments

\begin{tabular}{cccl}
\hline Treatment & $\begin{array}{c}\text { Jackfruit Pulp } \\
\text { Preparation }\end{array}$ & Packaging Method & Storage Condition \\
\cline { 1 - 2 } T1 & With seed & Vacuum Packed & Chilled \\
T2 & With seed & Vacuum packed & Ambient \\
T3 & With seed & Conventionally packed & Chilled \\
T4 & With seed & Conventionally packed & Ambient \\
T5 & Without seed & Vacuum packed & Chilled \\
T6 & Without seed & Vacuum packed & Ambient \\
T7 & Without seed & Conventionally packed & Chilled \\
T8 & Without seed & Conventionally packed & Ambient \\
\hline
\end{tabular}

\section{Physicochemical Analysis}

Evaluation of all physicochemical properties of freshcut jackfruit was done on the first until the 8th day of storage for every packaging method and storage condition.

Total Soluble Solids (TSS). The total soluble solids were measured using a hand refractometer (Atago ATC-IE model Japan). It was calibrated by placing a drop of distilled water on the prism of the refractometer. After calibrating, a drop of pure 
Physicochemical qualities of stored fresh cut

squeezed juice sample was placed on the prism of the hand refractometer. Then the reading was taken and recorded.

Titratable Acidity (TA). The TA was determined by employing the standard titration method using a standardized $0.1 \mathrm{~N} \mathrm{NaOH}$ solution. Five grams of the blended sample was diluted with $25 \mathrm{~mL}$ distilled water in a Florence flask. Then, 2-3 drops of phenolphthalein indicator was added. It was titrated with the standardized $0.1 \mathrm{~N} \mathrm{NaOH}$ solution until stable pink color was observed. This acidity was calculated according to the following formula:

$$
\% \mathrm{TA}(\text { citric acid })=\mathrm{V} \times \mathrm{N} \times \mathrm{M} / \mathrm{W} \times 100
$$

Where:

$$
\begin{aligned}
& \mathrm{V}=\text { volume of } \mathrm{NaOH} \text { added }, \mathrm{mL} \\
& \mathrm{N}=\text { concentration }(\mathrm{N}) \text { of } \mathrm{NaOH}, \\
& \mathrm{M}=\text { milliequivalent weight }(\mathrm{meq} / \mathrm{g}) \text { of predominant acid, } \\
& \mathrm{W}=\text { weight }(\mathrm{g}) \text { equivalent of aliquot, } \mathrm{g} \\
& \mathrm{W}=\frac{\text { weight of sample }(\mathrm{g})}{\text { vol.aliquot }} \times \text { vol.of water added }
\end{aligned}
$$

pH. The $\mathrm{pH}$ of sample was determined using a calibrated digital $\mathrm{pH}$ meter $(\mathrm{pH}-$ Pen PT-70). The $\mathrm{pH}$ of the sample was determined by dipping the $\mathrm{pH}$ meter electrode into a $5 \mathrm{~g}$ pureed sample. Pureed samples were prepared by blending $20 \mathrm{~g}$ pulp with $50 \mathrm{~mL}$ water in an osterizer, Three replications were done.

Color Measurement. For color measurement, colorimeter (Lovibond Colorimeter) was used to determine the color of all the treatments. Hunters $L$ and $b$ value were measured. Hunters $L$ represents the lightness of the color. The $b$ value represents the yellow/blue opponent where blue was at negative $b$ values and yellow is at positive $b$ values.

Degree of Browning. The modified method proposed by Baloch et al (1973) as cited in Mahayothee et al (2009) was used to evaluate the accumulation of the formation of brown pigments. The chopped sample $(5 \mathrm{~g})$ was soaked in $50 \mathrm{~mL}$ of $2 \%$ $(\mathrm{v} / \mathrm{v})$ acetic acid solution for $2 \mathrm{~h}$. Subsequently, the sample was placed in the plastic centrifuge tubes (50mL capacity) then centrifuged at 3,000ppm for $1 \mathrm{hr}$. The supernatant was obtained and the absorbance was read at $420 \mathrm{~nm}$ with UV-Vis double beam spectrophotometer (Genesys ${ }^{\mathrm{TM}} 10 \mathrm{~S}$, USA). Two percent acetic acid was used as a blank. Three readings were taken and the results were expressed as absorbance per weight of sample in dry basis.

Firmness Measurement. Firmness was measured using a fruit penetrometer to get the numerical rating of the pulps. Flat tip plunger was used. The sample was put in leveled surface to ensure stability of both the sample and the reading. The penetrometer was tared to zero, slowly plunged into the sample until it touched the very surface of the sample. The plunger was slowly pressed into the sample until a consistently firmness value appeared on the screen. The values were reported in 
$\mathrm{kg} / \mathrm{cm}^{2}$ force. Five readings were obtained and the mean was used in reporting the result.

\section{Statistical Analysis}

Data gathered from the physicochemical analysis were subjected to single factorial Analysis of Variance (ANOVA) for the readings of each treatment per day and Multi-factorial ANOVA to determine the interaction of dependent or response variables on the physicochemical properties of freshcut jackfruit. Interval as well as interaction plots were generated through factorial plots and time series plots using Minitab Express Software.

\section{RESULTS AND DISCUSSION}

\section{Physico-Chemical Quality}

\section{Total soluble solids}

The initial Total Soluble Solids of the product during day 0 has a mean of $25 \pm 1$ ${ }^{\circ}$ Brix. It was observed that there is no significant difference $(p \leq 0.05)$ on the TSS readings between treatments during $1^{\text {st }}$ and the 2 nd day, but apparent changes occurred during Day 3 onwards. The analysis of variance of the TSS of treatments during the 8th day storage period indicates that observed changes were mainly due to the storage temperature since it has the higher percentage of variance explanation (Table 2).

Table 2. Analysis of variance of TSS of fresh-cut jackfruit stored for 8 days

\begin{tabular}{ccccccccc}
\hline & & \multicolumn{7}{c}{ Storage Period (Day) } \\
\hline Main Effects & 1 & 2 & 3 & 4 & 5 & 6 & 7 & 8 \\
\hline A: preparation & 0.00 & 0.11 & 0.01 & 0.07 & 0.10 & 0.04 & 0.09 & 0.09 \\
B: packaging & 0.73 & 0.06 & 0.49 & 0.34 & 1.19 & $29.75^{* *}$ & 0.28 & 0.19 \\
method & & & & & & & & \\
$\begin{array}{c}\text { C: storage } \\
\text { condition }\end{array}$ & 1.11 & 4.32 & $5.95^{*}$ & $61.04^{* *}$ & $54.64^{* *}$ & $92.99^{* *}$ & $22.48^{* *}$ & $11.04^{*}$ \\
Interaction & & & & & & & & \\
A x B & 0.72 & 0.17 & 0.55 & 0.04 & 0.14 & 0.06 & 0.09 & 0.28 \\
A x C & 1.91 & $18.91^{* *}$ & 3.89 & 0.28 & 0.05 & 0.01 & 0.13 & 0.47 \\
B x C & 0.04 & 0.24 & 0.37 & $11.35^{*}$ & 6.30 & $19.17^{*}$ & 4.53 & 3.53 \\
\hline
\end{tabular}

$\star, \star \star, * * \star$ Significant to $p \leq 0.05,0.01$ and 0.001 , respectively.

Ambient temperatures caused increase in biochemical reactions in pulps. Fruit pulps which have living tissues continue the respiration process, consuming sugars and varying TSS levels, as mentioned by Lamikanra et al (2000). Cantwell and Suslow (2013) mentioned high respiration rates indicate a more active metabolism and usually a faster deterioration rate in fruit tissues. Higher respiration rates can result in more rapid loss of acids, sugars and other components that determine flavor quality and nutritive value (Cantwell \& Suslow 2013). Another observation noted was treatments with pulps with seed and stored at chilled condition also exhibit increase in their TSS at the early stage of storage (Figure 1). 
Physicochemical qualities of stored fresh cut
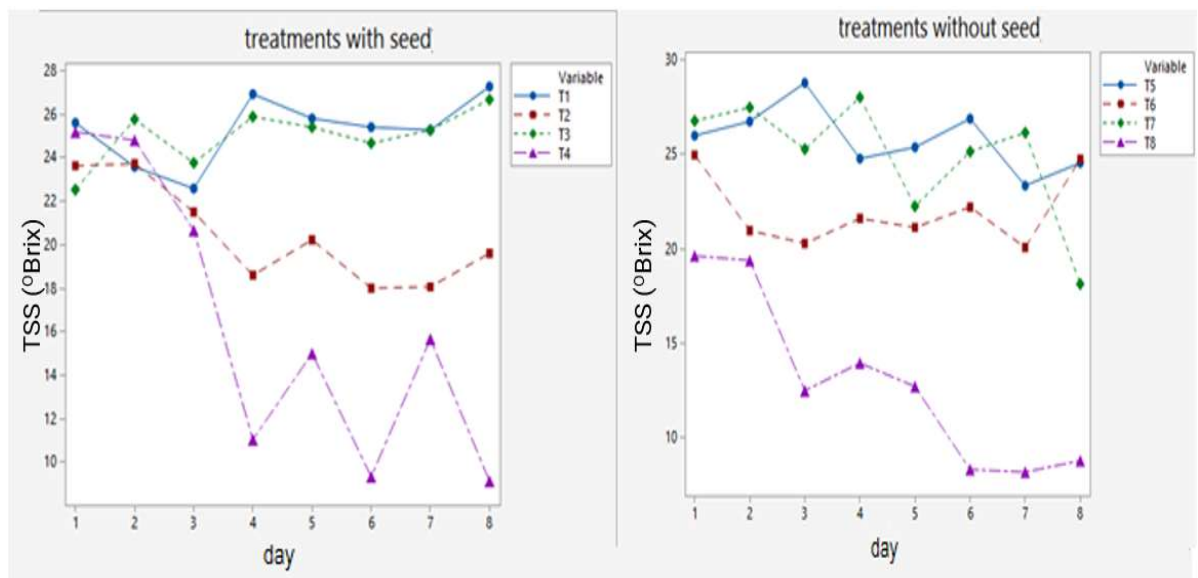

Figure 1. TSS ( ${ }^{\circ}$ Brix) of different treatments at different storage periods (T1-with seed, vacuumed and chilled, T2-with seed, vacuumed and ambient, T3- with seed, without vacuum and chilled, T4with seed, without vacuum and ambient, T5-without seed, vacuum and chilled, T6-without seed, vacuum and ambient, T7- without seed, without vacuum and chilled, T8- without seed, without vacuum and ambient)

Table 3. TSS reading of each treatment during the 8-day storage period

\begin{tabular}{cccccccccc}
\hline Treatments & D1 & \multicolumn{1}{c}{ D2 } & \multicolumn{1}{c}{ D3 } & \multicolumn{1}{c}{ D4 } & D5 & D6 & D7 & D8 & Mean \\
\hline 1 & 25.6 & 23.58 & 22.58 & 26.92 & 25.8 & 25.4 & 25.26 & 27.26 & 24.60 \\
2 & 23.6 & 23.72 & 21.5 & 18.6 & 20.22 & 18 & 18.06 & 19.6 & 20.26 \\
3 & 22.52 & 25.76 & 23.76 & 25.88 & 25.4 & 24.66 & 25.26 & 26.66 & 24.32 \\
4 & 25.17 & 24.8 & 20.66 & 11.04 & 15 & 9.33 & 15.66 & 9.13 & 16.64 \\
5 & 25.97 & 26.72 & 28.76 & 24.76 & 25.36 & 26.86 & 23.33 & 24.53 & 25.03 \\
6 & 24.95 & 20.96 & 20.28 & 21.6 & 21.12 & 22.2 & 20.06 & 24.73 & 21.66 \\
7 & 26.75 & 27.46 & 25.26 & 28 & 22.24 & 25.13 & 26.13 & 18.13 & 24.23 \\
8 & 19.62 & 19.38 & 12.5 & 13.96 & 12.72 & 8.33 & 8.2 & 8.8 & 13.61 \\
\hline
\end{tabular}

During storage, it was observed that TSS of the product is affected by storage condition and preparation method. Treatments stored in chilling $\left(4-6^{\circ} \mathrm{C}\right)$ condition exhibited lesser variation in the mean TSS reading during the 8-day storage period $(\mathrm{T} 1=24.6, \mathrm{~T} 3=24.32, \mathrm{~T} 5=25.03$ and $\mathrm{T} 7=24.23)$ compared to those stored at ambient temperature $(\mathrm{T} 2=20.26, \mathrm{~T} 4=16.64, \mathrm{~T} 6=21.66$, and $\mathrm{T} 8=13.61)$ ( $\mathrm{Table} 3$ ). It was observed that with longer storage time within treatments with the same type of preparation and packaging method the mean TSS decreased to minimum values after 8 days, with differences among them, and with significant differences from the initial TSS (Table 3). It was further observed that treatments which have intact fruit pulps (with seed) that were chilled have slight decrease in TSS during the 3-day storage period $( \pm 1.84)$ compared to treatments which are deseeded that shows abrupt decrease in TSS $( \pm 2.79)$. This can be explained by the fact that as a fruit tissue is ruptured, the rate of biochemical reactions increases thus consuming sugars in the process (Cantwell \& Suslow 2002). Freshcut processing increases 
respiration rates and causes major tissue disruption as enzymes and substrates normally sequestered within the vacuole, become mixed with other cytoplasmic and nucleic substrates and enzymes (Cantwell \& Suslow 2002). Processing also increases wound-induced ethylene, water activity and surface area per unit volume, which may accelerate loss and enhance microbial growth since sugars also become readily available (King \& Bolin 1989, Watada et al 1990, Wiley 1994, Watada \& Qi 1999).This drop in TSS content might also be explained by the fact that this early period (after minimal processing) would be characterized by an intensive respiration during which this sugar would be rapidly used as substrate in the metabolic process. The increase of TSS at the early stages of the chilled treatments might be due to metabolism of the cell wall polysaccharides producing sugars (Fennema 1985).

\section{Titratable Acidity}

The increase in TA as storage period increases may be affected by the fermentation in the product due to increased microbial activity. In a study of Aneja et al (2014), fresh fruit juices were spoiled due to high levels of molds and yeast attributable to the increase in acidity of the product. The presence of microorganisms especially yeast can cause fermentation which converts sugars into organic acids.

In Figure 2 fermentation in the product is evident as the packaging materials bloat (vacuum packed treatments) as storage period increases especially those stored at ambient storage condition. It was also observed that T1 (with seed at chilled storage condition) has maintained its vacuum throughout the storage period.

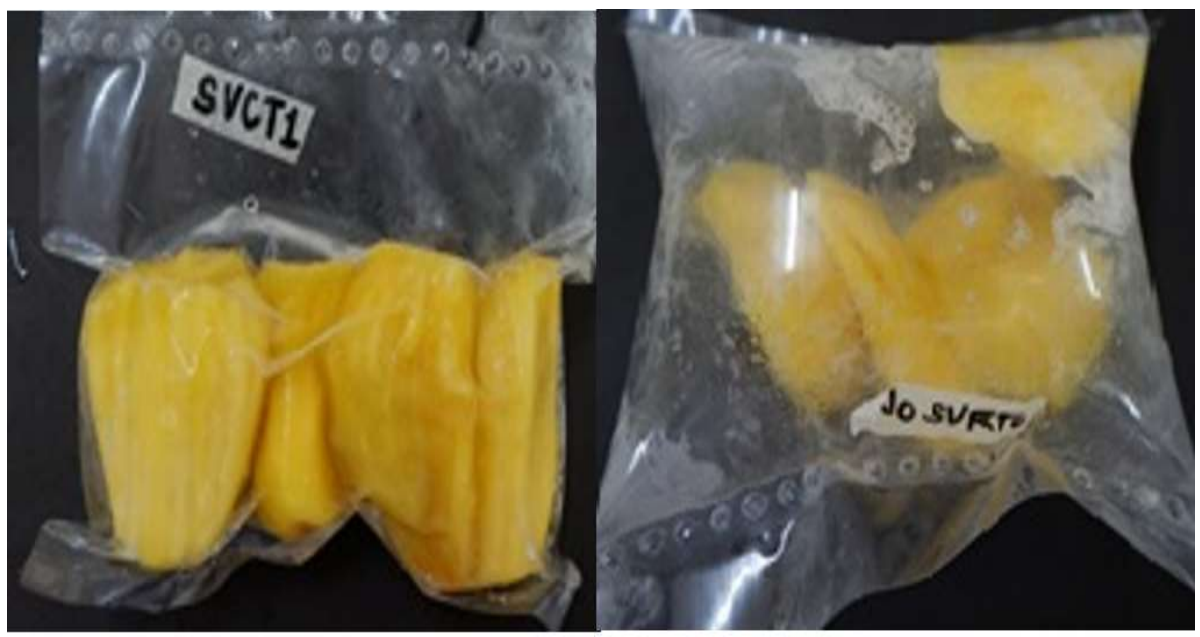

(a)

(b)

Figure 2. Vacuum packed freshcut jackfruit at (a) chilled and (b) ambient storage for 3 days 
Physicochemical qualities of stored fresh cut

Table 4. TA reading of each treatment during the 8-day storage period

\begin{tabular}{cccccccccc}
\hline Treatments & $\mathrm{D} 1$ & $\mathrm{D} 2$ & $\mathrm{D} 3$ & $\mathrm{D} 4$ & $\mathrm{D} 5$ & $\mathrm{D} 6$ & $\mathrm{D} 7$ & $\mathrm{D} 8$ & $\mathrm{D} 1$ \\
\hline \multirow{2}{*}{1} & 0.00 & 0.002 & 0.0027 & 0.002 & 0.002 & 0.0020 & 0.0027 & 0.0096 & 0.004 \\
& 4226 & 871 & 18 & 351 & 847 & 71 & 26 & 92 & 226 \\
2 & 0.00 & 0.004 & 0.0090 & 0.007 & 0.007 & 0.0086 & 0.0099 & 0.0103 & 0.002 \\
& 2094 & 273 & 33 & 988 & 87 & 23 & 53 & 47 & 094 \\
3 & 0.00 & 0.002 & 0.0025 & 0.003 & 0.003 & 0.0026 & 0.0026 & 0.0021 & 0.002 \\
& 2392 & 576 & 4 & 095 & 262 & 05 & 59 & 54 & 392 \\
4 & 0.00 & 0.002 & 0.0042 & 0.004 & 0.007 & 0.0041 & 0.0061 & 0.0028 & 0.003 \\
& 3251 & 417 & 88 & 454 & 135 & 5 & 74 & 53 & 251 \\
5 & 0.00 & 0.002 & 0.0033 & 0.002 & 0.002 & 0.0024 & 0.0037 & 0.0045 & 0.003 \\
& 3304 & 758 & 74 & 791 & 236 & 69 & 43 & 32 & 304 \\
6 & 0.00 & 0.006 & 0.0083 & 0.009 & 0.009 & 0.0094 & 0.0092 & 0.0099 & 0.003 \\
& 3855 & 072 & 35 & 684 & 03 & 95 & 17 & 66 & 855 \\
7 & 0.00 & 0.002 & 0.0027 & 0.003 & 0.002 & 0.0022 & 0.0038 & 0.0027 & 0.002 \\
& 2384 & 621 & 53 & 796 & 908 & 77 & 46 & 78 & 384 \\
8 & 0.00 & 0.005 & 0.0042 & 0.005 & 0.006 & 0.0043 & 0.0020 & 0.0099 & 0.004 \\
& 4525 & 569 & 7 & 44 & 329 & 25 & 85 & 82 & 525 \\
\hline
\end{tabular}

An increase in TA was observed in all treatments as storage time increased (Figure 3). It was observed that treatments stored at ambient temperature established a higher increase in TA relative to the initial TA reading $(0.0016 \pm 0.50 \%)$. TA and TSS reading established a relationship. As initial TSS decreased by $\leq 10.23$ during storage period, TA also increased by $\leq 0.007888$ (Table $3 \&$ Table 4). Table 5 shows the ANOVA of TA during the 8-day storage. It was observed that storage condition as well as packaging method greatly affected the TA of the product. And the interaction of factors: packaging method and storage temperature was highly significant starting Day 3.

This rapid increase in TA at treatments stored at ambient condition may be contributed to the fast respiration rate as well as increased microbial activity in the product. With the presence of fermentative microorganisms such as yeast and bacteria, fermentation takes place thus converts sugars into acid thus increasing $\%$ TA. As mentioned by Cantwell and Suslow (2013), low temperatures minimize differences in respiration and ethylene production rates between the fresh-cut and the intact product. Low temperatures are also essential to retard microbial spoilage on cut surfaces. 

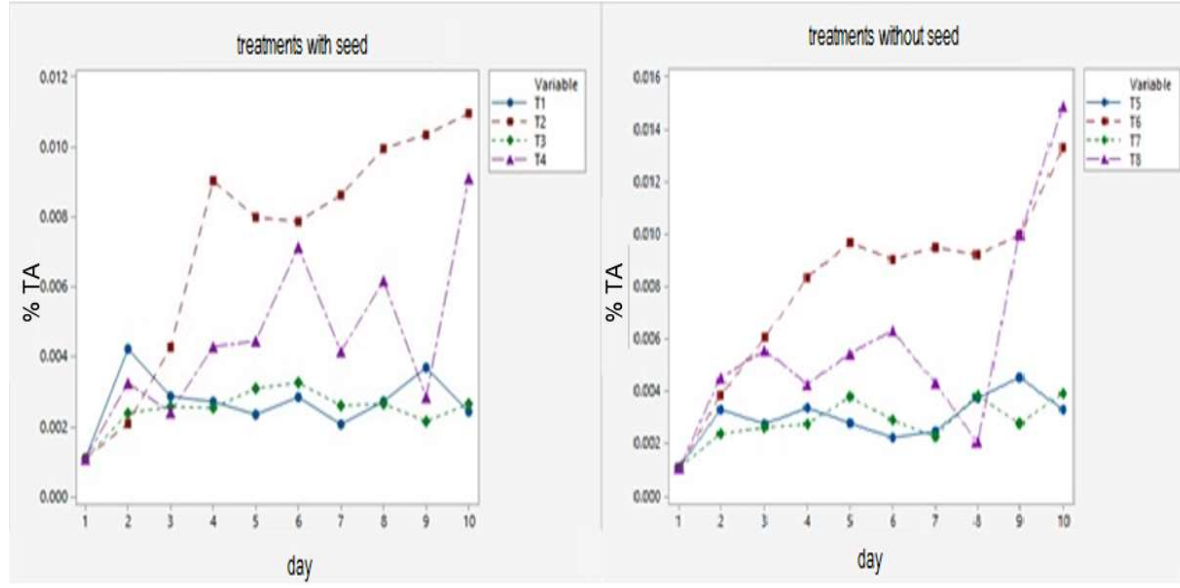

Figure 3.TA (\%TA as citric acid) of different treatments for 8-day storage period (T1-with seed, vacuum and chilled, T2-with seed, vacuum and ambient, T3- with seed, without vacuum and chilled, T4- with seed, without vacuum and ambient, T5-without seed, vacuum and chilled, T6without seed, vacuum and ambient, 77 - without seed, without vacuum and chilled, T8- without seed, without vacuum and ambient)

Table 5. Analysis of variance of TA of fresh-cut jackfruit stored for 8 days

\begin{tabular}{|c|c|c|c|c|c|c|c|c|}
\hline \multirow[b]{2}{*}{ Main Effects } & \multicolumn{8}{|c|}{ Storage Period (Day) } \\
\hline & 1 & 2 & 3 & 4 & 5 & 6 & 7 & 8 \\
\hline A: preparations & 0.44 & 1.10 & 0.00 & 0.17 & 2.21 & 0.01 & 0.07 & 0.06 \\
\hline $\begin{array}{l}\text { B: packaging } \\
\text { method }\end{array}$ & 0.08 & 0.36 & $95.84^{\star \star \star}$ & $8.01^{*}$ & 0.06 & $81.86^{* \star *}$ & 1.21 & 3.42 \\
\hline $\begin{array}{c}\text { C: storage } \\
\text { condition } \\
\text { Interaction }\end{array}$ & 0.36 & 14.80 & $219.39^{\star \star \star}$ & $53.20^{\star *}$ & $146.43^{\star \star \star}$ & $279.08^{\star \star \star}$ & $10.60 *$ & 2.51 \\
\hline$A \times B^{n s}$ & 0.02 & 0.11 & 0.00 & 0.00 & 0.03 & 0.02 & 0.10 & 2.15 \\
\hline$A \times C$ & 2.62 & $6.62^{*}$ & 0.06 & 0.07 & 0.21 & 0.02 & 0.76 & 1.10 \\
\hline$B \times C$ & 3.77 & 0.28 & $66.59^{\star \star \star}$ & $20.02^{*}$ & $8.20^{*}$ & $94.39^{\star \star \star}$ & 6.08 & 0.04 \\
\hline
\end{tabular}

$\star \star, * \star \star$ Significant to $p \leq 0.05,0.01$ and 0.001 , respectively.

$\mathrm{pH}$

As expected, general trend in $\mathrm{pH}$ readings showed that during the 8-day storage period, $\mathrm{pH}$ decreased at different treatment by $\leq 1.4$ (Table 6). The decrease in $\mathrm{pH}$ corresponds to the increase in TA during the storage period. As mentioned by Lea (1991), the $\mathrm{pH}$ is a logarithmic measure of the concentration of free hydrogen ions in a chemical or biological system, while titratable acid is a simple measure of the (related) amount of acid 'anions' in a juice. There is no direct relationship between titratable acidity and $\mathrm{pH}$, although generally the $\mathrm{pH}$ goes up as the acid goes down and vice-versa. The exact relationship differs from sample to sample and depends on esoteric concepts like 'buffering capacity' which will vary for a whole host of reasons. In general, titratable acid (TA) relates well to the 'acid taste' of a juice while $\mathrm{pH}$ relates more to microbial stability and susceptibility to mold and bacterial spoilage. 
Physicochemical qualities of stored fresh cut

Table 6. $\mathrm{pH}$ reading of each treatment during the 8-day storage period

\begin{tabular}{clcccccccc}
\hline Treatments & D1 & D2 & D3 & D4 & D5 & D6 & D7 & D8 & Mean \\
\hline 1 & 4.5 & 4.88 & 5.14 & 5.16 & 5.36 & 4.02 & 4.27 & 4.98 & 4.79 \\
2 & 4.53 & 4.46 & 4.02 & 5.2 & 3.88 & 4.02 & 4.03 & 3.86 & 4.25 \\
3 & 5.1 & 5.06 & 4.88 & 5.24 & 6.02 & 4.72 & 4.71 & 4.79 & 5.07 \\
4 & 4.78 & 5.26 & 4.92 & 5.5 & 5.6 & 4.18 & 4.19 & 4.61 & 4.88 \\
5 & 5.1 & 4.84 & 5.14 & 5.74 & 6.48 & 4.51 & 4.50 & 4.26 & 5.07 \\
6 & 5.08 & 4.54 & 4.68 & 5.68 & 4.62 & 3.89 & 3.89 & 3.83 & 4.53 \\
7 & 5.13 & 5.3 & 5.22 & 5.72 & 6.32 & 4.6 & 4.6 & 4.35 & 5.15 \\
8 & 4.55 & 4.96 & 4.88 & 5.76 & 4.96 & 4.36 & 4.36 & 3.95 & 4.72 \\
\hline
\end{tabular}

Figure 4 shows that treatments stored at ambient condition had higher decrease in $\mathrm{pH}$ compared to treatments stored at chilled conditions. As per mentioned in the previous statement, $\mathrm{pH}$ change is also an indicator of microbial quality. It was expected that treatments stored at ambient conditions would exhibit increase in fermentation rate because the environment of the microorganism was very favorable for microbial activity and growth. Period of handling of the pulps may have also contributed to microbial contamination thus deseeded samples $\left(T_{1}-T_{4}\right)$ exhibited lower $\mathrm{pH}$ reading compared to sample with intact pulps $\left(\mathrm{T}_{5}-\mathrm{T}_{8}\right)$ during the last day of storage period.

Table 7 shows the multifactorial ANOVA of $\mathrm{pH}$ readings. It was observed that interaction between factors is not significantly different, while preparation method is significant during Day 4, packaging during Day 2 and storage condition during Day 5 and Day 7. It was observed that treatments which were deseeded had more decrease in $\mathrm{pH}$ compared to intact fruit pulps (Figure 4). As the fruit tissue ruptures, surface area of the pulp increases thus contributed to the higher respiration rate of the product. When cells are ruptured by cutting during minimal processing, woundinduced biochemical reactions are initiated that shorten storage life (Cantwell \& Suslow 2013).
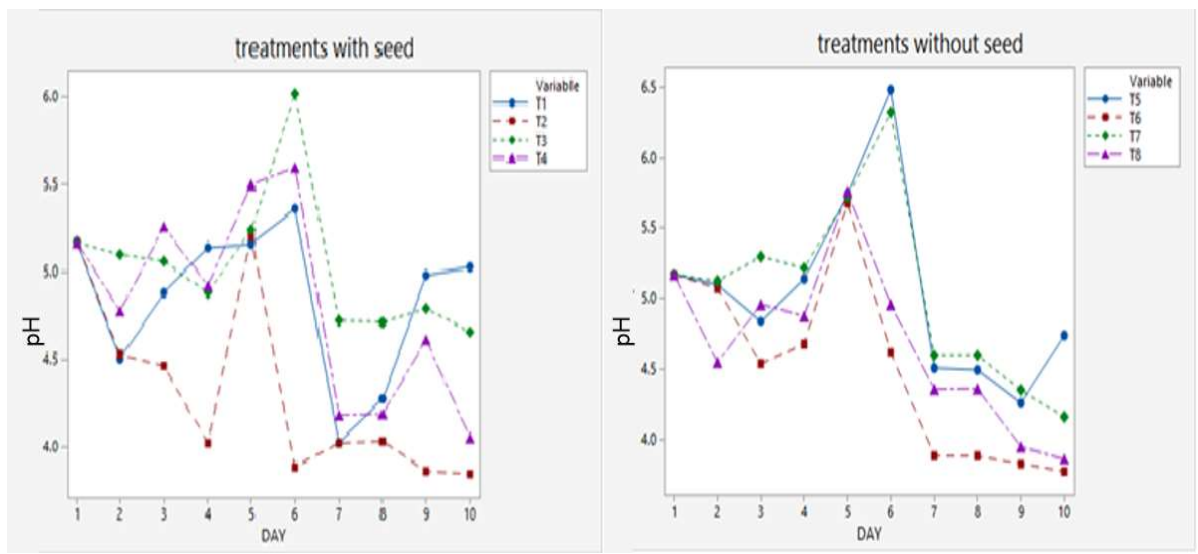

Figure $4 \mathrm{pH}$ of different treatments for 8-day storage period (T1-with seed, vacuum and chilled, T2-with seed, vacuum and ambient, T3- with seed, without vacuum and chilled, T4- with seed, without vacuum and ambient, T5-without seed, vacuum and chilled, T6-without seed, vacuum and ambient, T7- without seed, without vacuum and chilled, T8- without seed, without vacuum and ambient) 
Table 7. Analysis of variance of $\mathrm{pH}$ of fresh-cut jackfruit stored for 8 days

\begin{tabular}{lcccccccc}
\hline & \multicolumn{8}{c}{ Storage Period (Day) } \\
\cline { 1 - 9 } Main Effects & 1 & 2 & 3 & 4 & 5 & 6 & 7 & 8 \\
\hline A: preparation & 2.06 & 0.00 & 0.58 & $43.55^{\star \star}$ & 0.30 & 0.24 & 0.03 & 2.05 \\
B: packaging & 0.28 & $22.23^{\star \star}$ & 0.53 & 2.60 & 0.85 & 2.75 & $12.05^{\star}$ & 0.37 \\
C: storage con. & 1.13 & 0.70 & 6.39 & 0.09 & $11.39^{\star}$ & 6.45 & $22.59^{\star \star}$ & 4.02 \\
Interaction & & & & & & & & \\
A x B & 4.17 & 0.02 & 0.08 & 1.38 & 0.63 & 0.12 & 0.00 & 0.07 \\
A x C & 0.13 & 0.17 & 0.08 & 0.99 & 0.49 & 0.14 & 00.91 & 0.54 \\
B x C & 1.13 & 2.16 & 2.96 & 0.12 & 1.06 & 0.08 & 0.07 & 0.84 \\
\hline
\end{tabular}

$\star, \star \star, \star \star \star$ Significant to $p \leq 0.05,0.01$ and 0.001 , respectively.

Packaging method does not directly affect the $\mathrm{pH}$ of the product. According to Aneja et al (2014) fruit juices have $\mathrm{pH}$ in the acidic range (<4.5) serving as important barrier for microbial growth thus even at different packaging condition, change in $\mathrm{pH}$ is dictated by the natural physicochemical properties of the fruit as well the method of how it's handled.

\section{Color Evaluation}

The analysis of variance of the color parameters (Tables $8 \& 9$ ) shows that the interaction of the three factors was significant for lightness (Hunter $L^{*}$ value), and only packaging method and storage condition interaction was significant for yellowness (Hunter $b *$ value). As observed, the percentage of variance explanation is very low at all parameters due to the fact that even though the product has undergone fermentation and other quality degradation, the yellow color of the fruit is retained. According to Chichester et al (1965), the stability of various carotenoid pigments is a function of their association with cellular proteins and other substances. Thus, 3-carotene in commodities are relatively stable pigments which persist through prolonged storage.

Table 8. Analysis of variance for color parameter $\left(L^{*}\right)$ of fresh-cut jackfruit for 8-day storage period

\begin{tabular}{|c|c|c|c|c|c|c|c|c|}
\hline \multirow{2}{*}{ Main Effects } & \multicolumn{8}{|c|}{ Storage Period (Day) } \\
\hline & 1 & 2 & 3 & 4 & 5 & 6 & 7 & 8 \\
\hline A: preparation & 2.53 & 0.26 & 0.02 & 0.00 & 0.01 & 1.84 & 0.13 & $6.38^{\star}$ \\
\hline $\begin{array}{l}\text { B: packaging } \\
\text { method }\end{array}$ & 2.79 & $6.26^{*}$ & 2.53 & $7.19^{\star}$ & 0.41 & 1.83 & $11.15^{\star \star}$ & $5.21^{*}$ \\
\hline $\begin{array}{l}\text { C: storage } \\
\text { condition }\end{array}$ & 2.31 & $8.80^{* *}$ & 0.09 & $26.45^{\star \star \star}$ & 0.00 & 0.50 & $11.88^{\star \star}$ & 3.43 \\
\hline \multicolumn{9}{|l|}{ Interaction } \\
\hline$A \times B$ & 1.46 & 0.70 & $5.65^{\star}$ & 0.69 & 1.80 & 2.82 & 0.19 & 0.00 \\
\hline$A \times C$ & 0.44 & 3.87 & 0.04 & 3.64 & 0.94 & $5.20^{\star}$ & 0.21 & 0.04 \\
\hline $\mathrm{B} \times \mathrm{C}$ & 4.75 & 2.14 & 3.20 & 3.64 & $5.59^{*}$ & 2.12 & $43.88^{\star \star \star}$ & $10.68^{\star \star}$ \\
\hline
\end{tabular}

$*, * *, * * *$ Significant to $p \leq 0.05,0.01$ and 0.001 , respectively. 
Physicochemical qualities of stored fresh cut

Table 9. Analysis of variance for color parameter $(b *)$ of fresh-cut jackfruit

\begin{tabular}{ccccccccc}
\hline \multirow{2}{*}{ Main Effects } & \multicolumn{8}{c}{ Storage Period (Day) } \\
\cline { 2 - 9 } & 1 & 2 & 3 & 4 & 5 & 6 & 7 & 8 \\
\hline A: preparation & 1.95 & 0.04 & 0.05 & 0.05 & 0.37 & 0.05 & 0.00 & 0.03 \\
$\begin{array}{c}\text { B:packaging } \\
\text { method }\end{array}$ & 0.27 & 1.78 & 0.04 & 1.35 & 1.12 & $10.27^{\star}$ & 5.77 & 1.42 \\
$\begin{array}{c}\text { C:storage } \\
\text { condition }\end{array}$ & 1.19 & 3.30 & 1.45 & 1.88 & 2.84 & 3.65 & 0.06 & $19.45^{\star}$ \\
$\begin{array}{l}\text { Interaction } \\
\text { A x B }\end{array}$ & & & & & & & & \\
A x C & 0.47 & 0.80 & 0.23 & 2.03 & 0.08 & 0.02 & 0.15 & 0.02 \\
B x C & 0.66 & 1.17 & 1.52 & 0.17 & 0.33 & 0.38 & 0.30 & 0.22 \\
\hline
\end{tabular}

$, \star \star, \star \star *$ Significant to $P \leq 0.05,0.01$ and 0.001 , respectively.

Figure 5 shows the Hunter $b$ *. Positive $b *$ indicates yellowness of the product. Generally, it can be observed that treatments stored in ambient conditions $\left(T_{4}, T_{6}\right.$ \& $\left.T_{8}\right)$ have observable lower $b *$ than those stored at chilled conditions $\left(T_{3}, T_{5} \& T_{7}\right)$ except $T_{1}$. It can also be observed that deseeded pulp have lower Hunter $b^{\star}$ during the late day of storage compared to intact samples. This may be due to the browning of the pulps as tissues deteriorated during storage. This is in agreement with the findings of Galvez (2015) with dehydrated jackfruit pulps. Wounding increases rates of water loss, softening, and browning. Using very sharp tools to peel fruits and cut their flesh limits cellular damage and reduces leakage of cellular contents and enzymatic browning mediated by the enzymes polyphenol oxidase and phenol oxidase (Kader 2008).

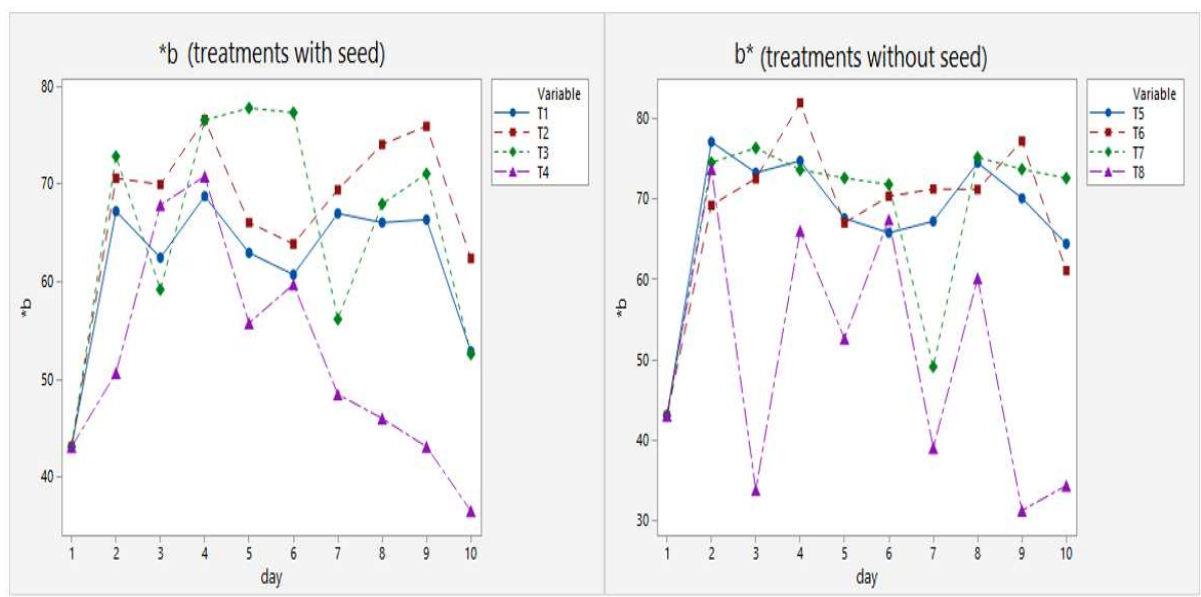

Figure 5 . Hunter $b \star$ of different treatments at different storage periods (T1-with seed, vacuum and chilled, T2-with seed, vacuum and ambient, T3- with seed, without vacuum and chilled, T4with seed, without vacuum and ambient, T5- without seed, vacuum and chilled, T6- without seed, vacuum and ambient, T7- without seed, without vacuum and chilled, T8- without seed, without vacuum and ambient) 


\section{Degree of Browning}

Accumulation of the formed brown pigments will dictate the degree of how physical property of the pulp has deteriorated in terms of firmness and color. As shown in the plots in Figure 6, deseeded pulp has a very evident increase in absorbance compared to intact pulps. As cited by Watada et al (1990), the practice of fresh-cut processing causes wounding, increases metabolic activities, and decompartmentalizes enzymes and substrates. This may cause browning, softening, decay, and off-flavor development.

Storage temperature greatly affects the degree of browning (Table 10). Treatments stored at room temperature have higher degree of Browning compared to those chilled (Figure 6). Biochemical reactions such as respiration speed up at higher temperatures. The increase in absorbance could be explained by nonenzymatic browning reactions such as the assumption that high temperature accelerated the carotenoid isomerization, which led to the loss of yellowness (Chen et al 1995).
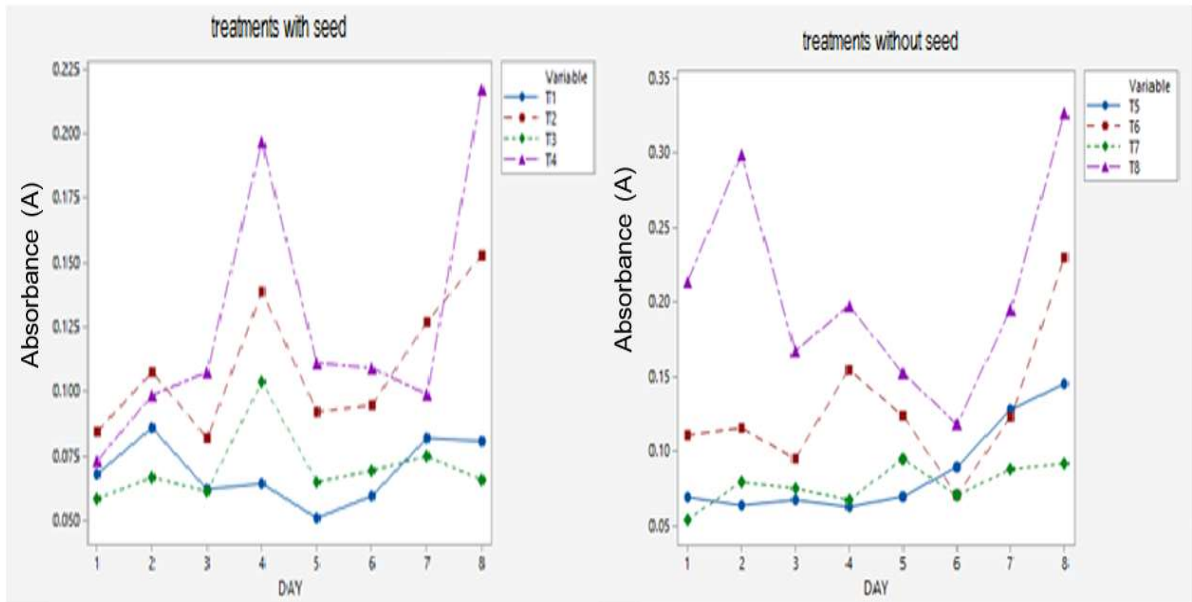

Figure 6 . Absorbance (A) of different treatments at different storage periods (T1-with seed, vacuum and chilled, T2-with seed, vacuum and ambient, T3- with seed, without vacuum and chilled, T4- with seed, without vacuum and ambient, T5-without seed, vacuum and chilled, T6without seed, vacuum and ambient, T7- without seed, vacuum and chilled, T8- without seed, without vacuum and ambient)

Table 10. Analysis of variance for absorbance parameter of fresh-cut jackfruit

\begin{tabular}{ccccccccc}
\hline \multirow{2}{*}{ Main Effects } & \multicolumn{8}{c}{ Storage Period (Day) } \\
\cline { 2 - 9 } & 1 & 2 & 3 & 4 & 5 & 6 & 7 & 8 \\
\hline $\begin{array}{c}\text { A: preparation } \\
\text { B:packaging } \\
\quad \text { method }\end{array}$ & 0.96 & 0.60 & 0.72 & 0.01 & 1.46 & 0.05 & 1.62 & 0.85 \\
$\begin{array}{c}\text { C:storage } \\
\quad \text { condition }\end{array}$ & 2.65 & 2.17 & $8.75^{*}$ & $96.13^{* \star *}$ & $10.10^{*}$ & 6.92 & 2.54 & $12.95^{\star}$ \\
$\begin{array}{l}\text { Interaction } \\
\text { A x B }\end{array}$ & & & & & & & & \\
A x C & 0.42 & 1.19 & 0.26 & 0.06 & 0.04 & 0.00 & 0.32 & 0.0 \\
B x C & 2.62 & 1.61 & 0.49 & 0.43 & 0.30 & 0.73 & 0.14 & 0.56 \\
\hline
\end{tabular}

$\star, * *, * * \star$ Significant to $P \leq 0.05,0.01$ and 0.001 , respectively. 
Physicochemical qualities of stored fresh cut

Biochemical reactions such as respiration speed up at higher temperatures. The increase in absorbance could be explained by nonenzymatic browning reactions such as the assumption that high temperature accelerated the carotenoid isomerization, which led to the loss of yellowness (Chen et al 1995). Another factor is the favorable environment for increase in microbial quality that causes the degradation of the tissues those results to browning.

\section{Firmness}

Results show that as time of storage increases, fruit pulp becomes softer thus readings in all the treatments decrease by approximately $\leq 0.77$ (Table 11). During fruit ripening, cell wall polysaccharides are extensively modified by a variety of ripening-related enzymes secreted from the symplast into the cell wall space. This process continues even after cutting open the fruit pulp. The changes affect the structure and strength of the wall, and ultimately bring about fruit softening (Brummell 2006). It was observed that packaging method and storage condition significantly affect the firmness of the pulps with storage (Table 12). As cited by Bruwell (2006), firmness is determined largely by the physical anatomy of the tissue, particularly cell size, shape and packing, cell wall thickness and strength, and the extent of cell-to-cell adhesion, together with turgor status.

Table 11. Penetrometer $\left(\mathrm{kg} / \mathrm{cm}^{2}\right)$ reading of each treatment during the 8-day storage period

\begin{tabular}{ccccccccccc}
\hline Treatments & D0 & D1 & D2 & D3 & D4 & D5 & D6 & D7 & D8 & Mean \\
\hline 1 & 1.29 & 1.25 & 1.06 & 0.97 & 1.04 & 1.27 & 0.99 & 1.21 & 1.24 & 1.11 \\
2 & 1.29 & 1.24 & 0.87 & 0.75 & 0.72 & 0.86 & 0.67 & 0.89 & 1.06 & 0.88 \\
3 & 1.29 & 1.11 & 1.06 & 0.99 & 0.82 & 1.08 & 1.22 & 1.22 & 1.18 & 1.09 \\
4 & 1.29 & 1.03 & 1.12 & 0.74 & 0.8 & 0.812 & 0.68 & 0.61 & 0.57 & 0.79 \\
5 & 1.29 & 1.24 & 1.09 & 0.92 & 1.17 & 1.16 & 0.9 & 1.04 & 1.62 & 1.14 \\
6 & 1.29 & 1.14 & 1.95 & 0.97 & 0.76 & 1.03 & 0.74 & 0.83 & 0.88 & 1.04 \\
7 & 1.29 & 1.08 & 0.95 & 1.01 & 1.32 & 0.75 & 1.18 & 1.07 & 1.04 & 1.05 \\
8 & 1.29 & 1.1 & 0.64 & 0.71 & 0.67 & 0.55 & 0.54 & 0.6 & 0.52 & 0.67 \\
\hline
\end{tabular}

Table 12. Analysis of variance for firmness parameter $\left(\mathrm{kg} / \mathrm{cm}^{2}\right)$ of fresh-cut jackfruit

\begin{tabular}{ccccccccc}
\hline \multirow{2}{*}{ Main Effects } & \multicolumn{7}{c}{ Storage Period (Day) } \\
\cline { 2 - 9 } & 1 & 2 & 3 & 4 & 5 & 6 & 7 & 8 \\
\hline A: preparation & 0.31 & 0.31 & 0.13 & 0.42 & 0.96 & 0.05 & 0.21 & 0.00 \\
$\begin{array}{c}\text { B:packaging } \\
\text { method }\end{array}$ & $16.41^{\star}$ & 1.64 & 0.13 & 0.01 & 4.29 & 0.12 & 0.30 & $11.16^{\star}$ \\
$\begin{array}{c}\text { C:storage } \\
\text { condition }\end{array}$ & 1.78 & 0.13 & $9.93^{\star}$ & $22.95^{\star \star}$ & 4.64 & $80.57^{\star \star \star}$ & $47.04^{\star \star}$ & $21.13^{\star}$ \\
Interaction & & & & & & & & \\
A x B & 1.22 & 3.30 & 0.13 & 0.06 & 1.44 & 0.03 & 0.01 & 0.12 \\
A x C & 0.01 & 0.26 & 0.64 & 6.07 & 0.28 & 0.02 & 0.47 & 0.31 \\
B x C & 0.15 & 0.60 & 2.77 & 0.01 & 0.02 & $14.33^{\star}$ & 5.49 & 0.22 \\
\hline
\end{tabular}

$, \star \star *, \star \star \star$ Significant to $P \leq 0.05,0.01$ and 0.001 , respectively. 
It was observed that treatments stored at ambient temperature have very significant decrease in the firmness of the pulp (Figure 7). While treatments stored at chilled condition and with intact pulps showed minimal changes in their firmness. For treatments stored at chilled condition, the firmness of the pulp was mostly retained or only changed slightly. This implies that the optimum condition for the storage of fresh-cut is in chilled conditions. Processes of plant senescence increase as the tissue of the harvested plant undergoes degradative changes in membranes, cell walls, subcellular organelles, proteins and texture. Wounding (fresh-cut processing) activates not only 1-aminocyclopropane-1-carboxylate (ACC) synthase but also ethylene production (Yu \& Yang 1980). For best quality retention of fresh-cut fruits, the preferred storage temperature is not higher than $5^{\circ} \mathrm{C}$, which is considered a chilling temperature for chilling sensitive tropical fruits (Dea et al 2010).
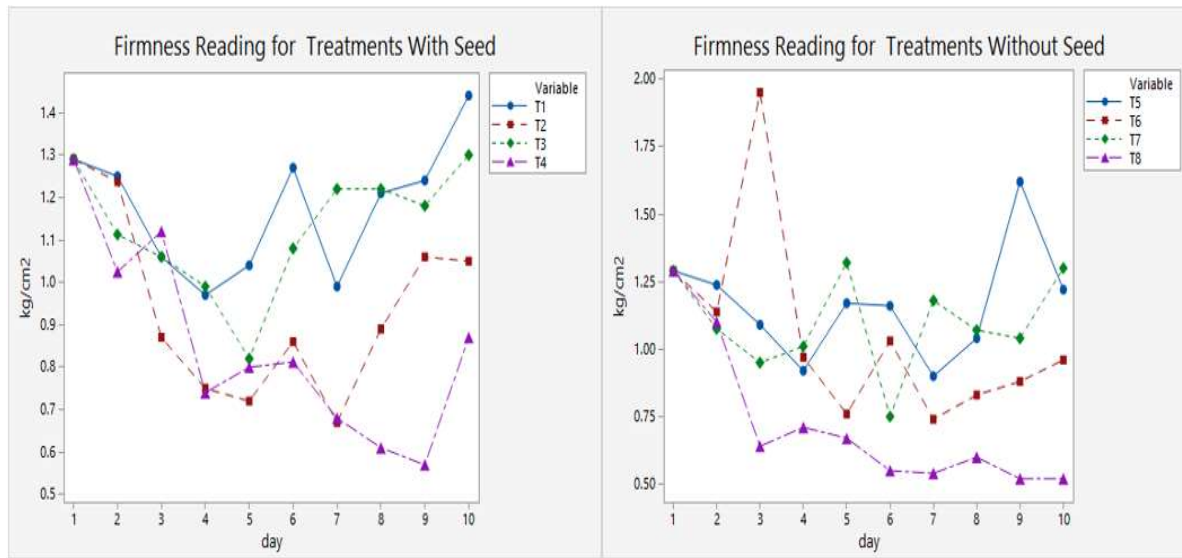

Figure 7. Firmness $\left(\mathrm{Kg} / \mathrm{cm}^{2}\right)$ of different treatments at different storage periods ( $\mathrm{T1}$-with seed, vacuum and chilled, T2-with seed, vacuum and ambient, T3- with seed, without vacuum and chilled, T4- with seed, without vacuum and ambient, T5-without seed, vacuum and chilled, T6-without seed, vacuum and ambient, T7- without seed, without vacuum and chilled, T8- without seed, without vacuum and ambient)

\section{CONCLUSIONS}

Deseeded products have faster deterioration compared to seed-intact treatments. Treatments stored in chilling $\left(4-6^{\circ} \mathrm{C}\right)$ condition exhibited lesser variation in TA, TSS, $\mathrm{pH}$, browning and firmness during the storage period compared to those stored at ambient temperature. Chilled treatments packed in vacuum have slower deterioration compared to treatments which are conventionally packed.

\section{IMPLICATION}

The study shows that for fresh cut jackfruit processing, it is essential to use intact-seeds pulp, vacuum packing and keeping in a low temperature storage to lengthen the shelf life of the product. 
Physicochemical qualities of stored fresh cut

\section{ACKNOWLEDGMENTS}

The researchers would like to thank Australian Centre for International Agricultural Research (ACIAR) \& Department of Science and Technology Accelerated Science and Technology Human Resource and Development Program(DOST-ASTHRDP) for funding this research.

\section{REFERENCES}

Aneja KR, Dhiman R, Aggarwal NK, Kumar V \& Kaur M. 2014 Microbes associated with freshly prepared juices of citrus and carrots. International Journal of Food Science 2014:1-7

Brecht JK, Sabaa-Srur AUO, Sargent SA \& Bender RJ. 1993. Hypochlorite inhibition of enzymatic browning of cut vegetables and fruit. Acta Horticulturae 343:341344

Brummell DA. 2006. Cell wall disassembly in ripening fruit. Functional Plant Biology 33(2):103-119

Cantwell M and Suslow T. 2002. Fresh-cut fruits and vegetables: Aspects of physiology, preparation, and handling that affect quality. Technology Horticultural Products 36(50):1-11

Chen HE, Peng HY \& Chen BH. Changes of carotenoids, color and vitamin A contents during processing of carrot juice. Journal of Agricultural and Food Chemistry 43(7):1912-1918.http://dx.doi.org/10.1021/jf00055a029

Chichester CO and Makayama TOM. 1965. Pigment changes insenescent and stored tissue. In Goodwin TW (ed) Chemistry and Biochemistry of Plant Pigments. Academic Press, London

Dea S, Brecht JK, Nunes C \& Baldwin EA.2010. Occurrence of chilling injury in freshcut 'Kent' mangoes. Postharvest Biology and Technology 57(2010):61-71

Fagundes C, Carciofi BAM \& Monteiro AR. 2013. Estimate of respiration rate and physicochemical changes of fresh-cut apples stored under different temperatures. Food Science Technology (Campinas) 33(1):60-67

Fennema OR.1985. Food Chemistry (2nd edn). Marcel Dekker, New York

Galvez LA. 2015. Variety and sulfite levels affect microbiological and sensory properties of dehydrated jackfruit (Artocarpus heterophyllus Lam) during storage. Annals of Tropical Research 37(2):93-103

Galvez LA and Dizon El. 2017. Physico-chemical and Functional Properties of Two Jackfruit (Artocarpus heterophyllus Lam) Varieties in Eastern Visayas, Philippines. Annals of Tropical Research 39 (2):100-106

Hurst WC. 1995. Sanitation of lightly processed fruits and vegetables. HortScience 30(1):22-24

Kader AA. 1986. Biochemical and physiological basis for effects of controlled and modified atmospheres on fruits and vegetables. Food Technology 40(5):99104

King AD Jr and Bolin HR. 1989. Physiological and microbiological storage stability of minimally processed fruits and vegetables. Food Technology 43(2):132-135 
Lamikanra O, Chen JC, Banks D \& Hunter PA. 2000. Biochemical and microbial changes during the storage of minimally processed cantaloupe. Journal of Agricultural and Food Chemistry 48(12):5955-5961

Lea AGH. 1991. Enzymes in the production of beverages and fruit juices. In Tucker GA and Woods LFJ (eds) Enzymes in food processing (pp194-220). Blackie \& Son Ltd. Glasgow

Mahayothee B, Udomkun P, Nagle M, Haewsungcharoen M, Janjai S \& Mueller J. 2009. Effects of pretreatments on colour alteration of litchi during drying and storage. Europe Food Research Technology 229(2):329-337

Patindol MR. 2016. Process optimization of minimally processed fresh-cut jackfruit (Artocarpus heterophyllus Lam.) (MS thesis). Visayas State University, Baybay City, Leyte, Philippines

Watada AE, Abe K \& Yamauchi D. 1990. Physiological activities of partially processed fruits and vegetables. Food Technology 44(5):116-122

Watada AE and Qi L. 1999. Quality of fresh-cut produce. Postharvest Biology and Technology 15(3):201-205

Wiley RC. 1994. Minimally processed refrigerated fruits and vegetables. Chapman and Hall, London, UK 